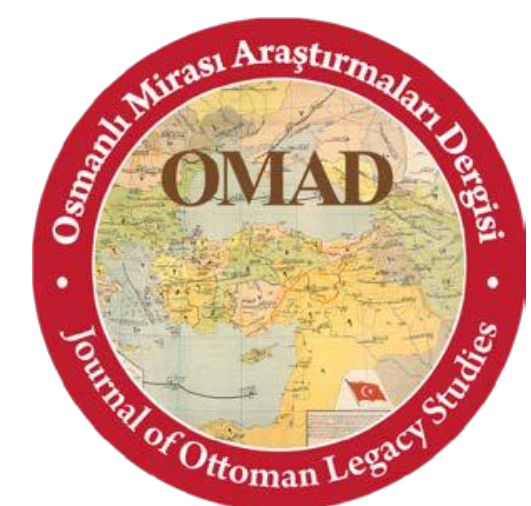

Osmanlı Mirası Araştırmaları Dergisi / Journal of Ottoman Legacy Studies

ISSN 2148-5704

www.osmanlimirasi.net

osmanlimirasi@gmail.com

Cilt 6, Sayı 14, Mart 2019 / Volume 6, Issue 14, March 2019

\title{
TRABZONLU FİGÂNî VE YAYIMLANMAMIŞ BİR GAZELİ
}

Figânî of Trabzon and His Unpublished Ode

Makale Türü/Article Types : Araştırma Makalesi/Research Article

Geliş Tarihi/Received Date : 02.01.2019

Kabul Tarihi/Accepted Date : 30.01.2019

Sayfa/Pages : $37-47$

DOI Numaras1/DOI Number : http://dx.doi.org/10.17822/omad.2019.110

\section{HAMZA KOÇ}

(Dr. Öğr. Üyesi), Giresun Üniversitesi, Fen Edebiyat Fakültesi, Türk Dili ve Edebiyatı Bölümü, Giresun / Türkiye, e-mail: vaveyla-61@hotmail.com, ORCID: https:/ /orcid.org/0000-00028324-3707

\section{Atıf/Citation}

Koç, Hamza, "Trabzonlu Figânî ve Yayımlanmamış Bir Gazeli", Osmanlı Mirası Araştırmaları Dergisi, 6/14, 2019, s. 37-47.

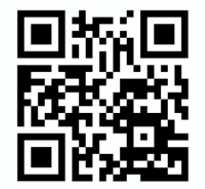

Scan me 



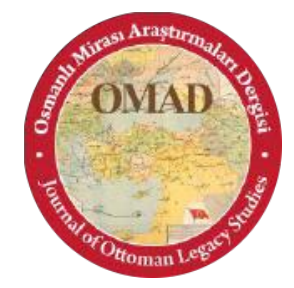

Osmanlı Mirası Araştırmaları Dergisi (OMAD), Cilt 6, Sayı 14, Mart 2019.

Journal of Ottoman Legacy Studies (JOLS), Volume 6, Issue 14, March 2019.

ISSN: $2148-5704$

\section{TRABZONLU FİGÂNî VE YAYIMLANMAMIȘ BİR GAZELİ Figânî of Trabzon and His Unpublished Ode}

\section{HAMZA KOÇ}

Öz: XVI. yüzyılın başlarında Trabzon'da doğan Figânî'nin asıl adı Ramazan'dır. Şair; delikanlılık çağındayken İstanbul'a gelmiş, sürekli olmamakla beraber iyi bir öğrenim görmüş, özellikle gramer, hekimlik ve edebiyatta kendisini yetiştirmiştir. Genç yaşlarda şiir yazmaya başlayan şair, ilk şiirlerinde Hüseynî mahlasını kullansa da Figânî'de karar kılmıştır. Figânî’nin şöhrete kavuşmasını sağlayan en önemli şiiri, Kanuni Sultan Süleyman'ın şehzadeleri Mustafa, Mehmed ve Selim'in sünnet düğünlerinde okuduğu Sûriyye kasidesidir. Bu kaside ile Figânî'nin itibarı artar fakat düşmanları çoğalır. Zira padişaha ve devlet adamlarına yazdığı kasidelerle onların yakınlığını kazanacağından korkan haset kişiler, Figânî’ye karşı düşmanca tavır takınırlar ve bunun önüne geçmek için vesileler aramaya başlarlar. Nihayetinde iftiraya kurban giden şair; Sadrazam Makbul İbrahim Paşa'nın, Mohaç'ta kazanılan büyük zaferin ardından İstanbul'a getirterek Atmeydanı'ndaki sarayının önüne diktirdiğgi heykeller üzerine dilden dile dolaşan bir Farsça beytin kendisine isnat edilmesi yüzünden adı geçen Paşa tarafından katledilir. Dönemin tezkire yazarlarının, yaşasaydı divan şiirinin en büyük sanatkârlarından biri olacağı konusunda hemfikir olduğu Figânî, genç yaştaki ölümü sebebiyle derli toplu bir divan tertip edemez. Ancak şiir tekniğindeki kudreti ve büyüleyici üslubu sayesinde çağının makbul şairleri arasına girebilmeyi başaran Figânî’nin, birçok şiir mecmuasında şiirlerine rastlamak mümkündür. Çalışmada Topkapı Sarayı Müzesi Ktp. Revan 1985 numarada kayıtlı 173 varaklık bir şiir mecmuasından hareketle, şairin yayımlanmadığı tespit edilen bir gazelinin metni verilecektir.

Anahtar Kelimeler: XVI. yüzyı1, Trabzonlu Figânî, şiir mecmuası, Divançe, yayımlanmamış gazel

Abstract: Born in Trabzon at the beginning of the $16^{\text {th }}$ century, the poet Figânî entered the world as Ramazan. He had settled in Istanbul during his youth, which is where he would ultimately receive a sound education and become versed in grammar, medicine, and literature. His first attempts at writing poetry had occurred during his youth under the penname Hüseynî, however he would later settle upon the pseudonym Figânî instead. The poem in which would grant him his golden ticket to fame was the ode Sûriyye, in which he had recited at the circumcision ceremonies of Suleiman the Magnificent's three sons, the princes Mustafa, Mehmed, and Selim. Despite the tremendous respect that his ode had awarded him, Figânî would also end up becoming the enemy of a great many this, given that those who were afraid, and thus jealous of the fact his poetry might bring him closer to both the sultanate as well as statesmen/politicians, had in turn lead them to both lash out against him, as well as to find a means of blocking him. In the grand scheme of things, he would ultimately fall victim to those who despised him. He would eventually be brought to Istanbul again and slaughtered at the hands of the grand vizier Makbul İbrahim Pasha due to a circulating Persian poem written by Figânî about the statues in front of the palace at in Atmeydanı that were erected upon his majesty's victory at Mohaç, and that makes mention of Pasha. Were Figânî to have lived longer, he would have been the single most important divan poet of his period [or so was the consensus of biography or tezkire writers of the day]. Unfortunately, his early death prevents us from ever being able to know this. Despite this, his powerful and captivating technique and tone in his poetry has nevertheless won him a spot among the favored wordsmiths of his era. Moreover, it is possible to find a great number of his poems scattered throughout many an Ottoman poetry miscellany. In this study will be presented the original copy of one of Figânî’s unpublished odes as found in a poetry miscellany housed at the Topkap1 Palace Library, catalogue number 173, Revan 1985.

Keywords: $16^{\text {th }}$ century, Figânî of Trabzon, poetry miscellany/mecmua, Divançe, unpublished ode 


\section{Giriş}

Asıl adı Ramazan olan Figânî, Trabzonludur. ${ }^{1}$ Riyâzî, adının yanına "Çelebi” sıfatını ekleyerek şairi "Ramazan Çelebi" şeklinde anmaktadır. ${ }^{2} \mathrm{Ne}$ yazık ki tezkireler, şairin ailesi konusunda sükût ederler. Onun hakkında en teferruatlı bilgi veren Âşık Çelebi bile bu konuda herhangi bir bilgi vermez. Figânî'den senelerce sonra eser veren Bağdatlı İsmail Paşa, şairin babasının adının Abdullah olduğunu belirtmekle yetinir. ${ }^{3}$ Adının ve doğum yerinin kesinlikle bilinmesine rağmen doğum yılı hakkında kaynaklarda herhangi bir bilgiye rastlanmaz. Ancak şiirlerindeki bazı ipuçlarına ve tezkirelerle tarihçilerin genç yaşta katledildiğine dair açıklamalarına bakılacak olursa Figânî’nin -aşağı yukarı- XVI. yüzyılın ilk birkaç yılı içerisinde doğduğu söylenebilir. Çocukluğu ve ilk gençliği hakkında bilgi edinilemeyen şairin delikanlılık çağındayken İstanbul'a geldiği, sürekli olmamakla beraber iyi bir öğrenim gördüğü, özellikle gramer, hekimlik ve edebiyatta kendini yetiştirdiği anlaşılmaktadır. ${ }^{4}$ Âşık Çelebi; kısa süren medrese tahsilinin ardından şiire yöneldiğini, dolayısıyla sair ilimlere hevesi terk ederek şiir yazdığını ve mukataat kâtipliğine kanaat ettiğini söyler. ${ }^{5}$ Sehî ve Latîfî, tıp ilmiyle ilgilendiğini ve dönemin meşhur tabiplerinden Hakîm Şah Muhammed'den tıp tahsil ettiğini belirtirler. ${ }^{6}$ Gelibolulu Mustafa Âlî; Figânî’nin, birçoğu hekim olan Acem şairlerine benzemek istediği için tıbba merak sardığı görüşündedir. ${ }^{7}$ Fakat şairin tıp eğitimini tamamlayıp tamamlayamadığına dair elimizde herhangi bir belge yoktur. Hasan Çelebi ise Figânî’nin sarf ve nahiv ilmi ile meşgul olduğunu, ardından da belagat ve fesahat öğrenerek asrın âlim şairleri arasında yer aldığını ifade eder. ${ }^{8}$ Kaynaklarda Figânı̂’nin vurgu yapılan en önemli özelliklerinden biri de ögrenme ve ezberleme konusundaki yeteneğidir. Latîfí; onun Arapça ya da Farsça ne tür bir ibare olursa olsun, okur okumaz kolayca kavrayabildiğine, bir şiiri bir kere gözden geçirmekle taşa kazınan yazı misali hatırında tutabildiğine ve aklına gelen bir hususu müsvedde kâğıt kullanmaksızın hatasız bir şekilde yazıya dökebildiğine dikkat çeker. ${ }^{9}$

Koruyucusuz ve sahipsiz olarak büyük bir şehrin ortasına atılan Figânî, ne yaptığını bilememekten mi, aile baskısından veya kontrolünden kurtulmaktan mı kaynaklandığı belli olmayan bir hayatı yaşamaya başlar. ${ }^{10}$ Genç yaştan itibaren derli toplu bir hayat kuramayan şair, ilmin çok çalışma, sabır ve süreklilik gerektiren sıkı düzenine de ayak uyduramaz ve bunun yerine şiirin ilhama elverişli havasına kapılarak bu uğraşı benimser. ${ }^{11}$ Kendisi gibi şair olan

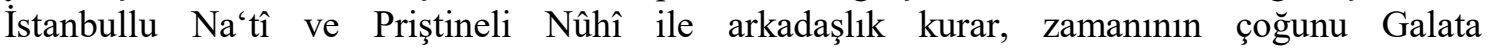

\footnotetext{
${ }^{1}$ Kınalı-zade Hasan Çelebi, Tezkiretü 'ş-şuarâ, C. II, Haz. İbrahim Kutluk, Türk Tarih Kurumu Yay., Ankara 1989, s. 763; Künhü'l-Ahbâr'ın Tezkire Kısmı, Haz. Mustafa İsen, Atatürk Kültür Merkezi Yay., Ankara 1994, s. 256; Şemsettin Sâmi, Kâmûsu'l-A’lâm, C. V, Kaşgar Neşriyat, Ankara 1996, s. 3417; Mehmed Süreyyâ, Sicill-i Osmanî Yahud Tezkire-i Meşâhir-i Osmâniyye, C. IV/I, Hazırlayanlar: Mustafa Keskin vd., Sebil Yay., İstanbul 1997, s. 28; Beyâni Mustafa Bin Carullah, Tezkiretü 'ş-Şuarâ, Haz. İbrahim Kutluk, Türk Tarih Kurumu Yay., Ankara 1997, s. 211; Sehî Bey Tezkiresi Heşt Behişt, Haz. Mustafa İsen, Akçağ Yay., Ankara 1998, s. 225; Latîfî, Tezkiretü'şŞu'arâ ve Tabsıratü'n-Nuzamâ (İnceleme-Metin), Haz. Rıdvan Canım, Atatürk Kültür Merkezi Başkanlığı Yay., Ankara 2000, s. 438; Mehmet Nâil Tuman, Tuhfe-i Nâilî Divân Şâirlerinin Muhtasar Biyografileri, C. II, Hazırlayanlar: Cemâl Kurnaz-Mustafa Tatc1, Bizim Büro Yay., Ankara 2001, s. 779; Ahdî ve Gülşen-i Şu'arâsı (Inceleme-Metin), Haz. Süleyman Solmaz, Atatürk Kültür Merkezi Başkanlığı Yay., Ankara 2005, s. 466; Âşık Çelebi, Meşâ 'irü'ş-Şu'arâ İnceleme-Metin, C. III, Haz. Filiz Kılıç, İstanbul Araştırmaları Enstitüsü Yay., İstanbul 2010, s. 1203; Riyâzî Muhammed Efendi, "Riyâzü’ş-Şuara", Haz. Namı Açııöz, http://ekitap.kulturturizm.gov.tr/Eklenti/54137,540229-riyazu39s-suarapdfpdf.pdf?0, erişim tarihi: 19.12.2018.

${ }^{2}$ Riyâzî Muhammed Efendi, age., s. 260.

${ }^{3}$ Cemil Çiftçi, Maktul Şairler, Kitabevi Yay., İstanbul 1997, s. 181.

4 Abdülkadir Karahan, Kanunî Sultan Süleyman Çă̆ Şairlerinden Figanî ve Divançesi, İstanbul Üniversitesi Edebiyat Fakültesi Yay., İstanbul 1966, s. XIII.

${ }^{5}$ Âş1k Çelebi, age., s. 1203.

${ }^{6}$ Latîfî, age., s. 438; Sehî Bey Tezkiresi Heşt Behişt, s. 225.

${ }^{7}$ Künhü'l-Ahbâr'ın Tezkire Klsmi, s. 256.

${ }^{8}$ Kınalı-zade Hasan Çelebi, age., s. 763.

${ }^{9}$ Latîfî, age., s. 438.

${ }^{10}$ C. Çiftçi, age., s. 182.

${ }^{11}$ A. Karahan, age., s. XIV.
} 
meyhanelerinde içki içmeye, Atmeydanı'nda başıboş gezip tozmaya ve güzeller peşinde koşmaya ayırır. ${ }^{12}$

Genç yaşta şiir yazmaya başlayan Figânî, ilk şiirlerinde Hüseynî mahlasını kullanmış; ancak daha sonra Figânî’yi tercih etmiştir. ${ }^{13}$ Geçimini daha çok devlet büyüklerine yazdığı kasidelerden elde ettiği bağışlar ve onların verdiği görevlerle sağlayan şair, mukataat kâtipliği görevinden eline geçen para yetmediği için sık sık yoksulluktan şikâyet eder. Bunu, Kanuni Sultan Süleyman'a yazdığı iki kaside başta olmak üzere Sadrazam İbrahim Paşa'ya, Cenâbî Bey'e ve başkalarına sunduğu övgü şiirlerinde nazik bir eda ile dile getirir. ${ }^{14}$ Hasan Çelebi'nin verdiği bilgilerden hareketle Figânî'nin, Kara Bâlîzâde ve onun vasıtasıyla tanıdığı Defterdar İskender Çelebi tarafından korunduğu anlaşılmaktadır. ${ }^{15}$ Bununla beraber Figânî, hiçbir zaman şiirle daha fazla uğraşacak ve arzularını gerçekleştirecek müreffeh bir hayata kavuşamamıştır. Zaman zaman elinden tutanlar olmuşsa da savurganlığı ve işrete düşkünlüğü kazancını çabucak yok etmiştir. Bir ara Edirne'ye gitmiş, bir süre de Seyyid Battal Gazi Türbesi etrafindaki zaviyede yaşamış, fakat sürekli ikamet mahalli İstanbul olmuştur. ${ }^{16}$

Figânî’nin şöhrete kavuşmasını sağlayan en önemli şiiri, Kanuni’nin şehzadeleri Mustafa, Mehmed ve Selim'in sünnet dügünlerinde okuduğu Sûriyye kasidesidir. Beyânî; bu görkemli düğünde kaside sunmak için birçok şairin bir araya geldiğini, ancak Figânî’nin arz ettiği kaside karşısında kendi şiirlerinin bir anlam ifade etmeyeceğini ve beğenilmeyeceğini anlayan şairlerin gizlice ortalardan kaybolduklarını ifade eder. ${ }^{17}$ Bu kaside ile Figânî'nin itibarı artar, düşmanları çoğalır. Genç ve yetenekli olması nedeniyle gururlanan şair, çağdaşlarına sataşmaya başlar. Padişaha ve devlet adamlarına yazdığı kasidelerle onların yakınlığını kazanacağından korkan haset kişiler, Figânî'ye karşı düşmanca tavır takınırlar. ${ }^{18}$ Muarızları, Kara Bâlîzâde ve Defterdar İskender Çelebi'den sonra bir de İbrahim Paşa tarafından esaslı şekilde himayeye kavuşmasından endişe ederler. Bunun önüne geçmek için vesileler ararlar ve uygun bir zaman kollarlar. Nihayet o sıralarda müsait bir imkân zuhur edince ellerinden geleni yaparlar ve şairin başına büyük bir bela getirmek suretiyle katline sebep olurlar. ${ }^{19}$

Bilindiği üzere Kanuni; 1526 y1lında üçüncü seferini düzenlemiş, Petervaradin’i almış, Mohaç’ta büyük bir zafer kazanmış ve Budin'e girmiştir. Böylece bağımsız Macar Krallığına da son verilmiştir. Buradan alınan hazine ile iki büyük tunç şamdan, üç heykel ve başka şeyler gemilerle Tuna Nehri üzerinden İstanbul'a getirilmiştir. Tunçtan yapılmış olan Herkül, Apollon ve Diyana heykelleri Atmeydanı'nda Makbul İbrahim Paşa Sarayı'nın önüne mermer tabanlar üzerine dikilmiştir. ${ }^{20}$ Bunun üzerine İbrahim Paşa'nın düşmanları, firsat bu firsattır diyerek

\footnotetext{
${ }^{12}$ Âşık Çelebi, age., s. 1203.

${ }^{13}$ Kinal1-zade Hasan Çelebi, age., s. 766.

${ }^{14}$ A. Karahan, age., s. XV.

${ }^{15}$ Kinal1-zade Hasan Çelebi, age., s. 764.

${ }^{16}$ Abdülkadir Karahan, "Figânî", Diyanet Vakfi İslam Ansiklopedisi, Cilt: 13, Türkiye Diyanet Vakfı Yay., Ankara 2018, s. 57.

${ }^{17}$ Beyâni Mustafa Bin Carullah, age., s. 211.

${ }^{18}$ C. Çiftçi, age., s. 182.

${ }^{19}$ Abdülkadir Karahan, "XVI. Asır Divan Şairlerinden Figânî ve Şiirleri”, İstanbul Üniversitesi Edebiyat Fakültesi Türk Dili ve Edebiyatı Dergisi, Sayı: 3 (3-4), 1949, s. 403.

${ }^{20}$ A. Karahan, age., s. XIX-XX. / Makbul İbrahim Paşa'nın, bugün Yunanistan sınırları içerisinde bulunan Parga yakınlarında bir köyde doğduğu ve altı yaşında İstanbul'a getirildiği genellikle kabul edilirse de hayatının ilk yılları hakkında kesin bir bilgi yoktur. Ayrıca II. Bayezid devrinde bir akın sırasında ele geçirilip Kefe'de bulunan Şehzade Süleyman'a takdim edildiği veya Pargalı bir gemicinin oğlu olup Türk korsanları tarafından esir alınarak Manisa civarında dul bir kadına satıldığı, ardından Manisa'da bulunan Şehzade Süleyman'ın hizmetine girdiği de rivayet edilir. Pargalı, Frenk ve Maktul gibi lakaplarla da anılır. Muhtemelen daha Manisa'da iken Şehzade Süleyman'ın en yakın adamı oldu, tahta geçmesi üzerine de onunla birlikte İstanbul'a gitti. Padişaha olan yakınlığ sebebiyle sarayda önemli görevlerde bulundu. Belgrad seferi (927 / 1521) sırasında kapı ağası olarak görev yapıyordu. Bu sefere çıkılırken masrafları Kanuni Sultan Süleyman tarafından karşılanan Atmeydanı'ndaki sarayının inşası başlatılmıştı. Padişaha olan bu yakınlığı giderek nüfuz ve gücünün artmasına yol açtı. Has odabaşı ve iç şahinciler ağası oldu. Rodos seferine katıldı (928 / 1522). Nihayet Pîrî Mehmed Paşa'nın azli üzerine o zamana kadarki teamüle aykırı olarak has odabaşılıktan Rumeli beylerbeyiliğiyle veziriazam oldu (13 Şaban 929 /
} 
veziri putperestlikle suçlarlar ve "İbrâhîm Paşa dahı müslümân olmayup büt-perestlikden ferâgat itmemiş." diyerek etrafa çeşitli dedikoduların yayılmasına sebep olurlar. Ortalık bu söylentilerle çalkalanırken Figânî'yi çekemeyenler de boş durmaz ve İbrahim Paşa'ya gidip "Seni bu beyitle hicvetti." diyerek aşağıdaki Farsça manzumeyi okurlar:

Dü İbrâhîm âmed be-deyr-i cihân

Yekî büt-şiken şud yekî büt-nişânn ${ }^{21}$

İbrahim Paşa, nifak ehlinin bu hilesine aldanıp gazaba gelir ve günahsız şairi apar topar evinden aldırıp önce dövdürür sonra da Hallac-1 Mansur misali astırır. Hasan Çelebi, Figânı̂’nin sebepsiz yere öldürülmesinden duyduğu derin üzüntüyü şu kıta ile dile getirir:

\section{Çıkdı gerçi zâhiren cism-i Figânî göklere \\ Döne döne çıkdı çak âh u figânı göklere}

\section{Mâteminde âsmânî giydi gökler yâ meger}

Boyadı anun duhânı âsmânı göklere ${ }^{22}$

Taşlıcalı Yahya Bey de çağdaşı Figânî’nin öldürülmesi olayından oldukça etkilenmiş ve Hamse'sindeki Kitâb-ı Usûl mesnevisinin altıncı makamında bu konuya yer vermiştir. ${ }^{23}$

Âşık Çelebi, şairin katledilişini detaylı bir şekilde anlatmaktadır: Figânî’nin asılmasından üç gün önce bir akşam vakti şuara ve zurefa zümresinden birçok kişi, eğlenmek için Kara Bâlîzâde'nin evinde toplanırlar. Herkes yiyip içip hoşça vakit geçirirken Figânî o gece tek bir kelime bile etmez. Ertesi gün eğlence devam etse de şairin suratı asık, gönlü hüzünlüdür. $\mathrm{Bu}$ durum Kara Bâlîzâde'nin dikkatini çeker ve Figânî’ye neden üzgün olduğunu sorar. Bu soru karşısında biraz duraksayan şair, bir rüya gördüğünü ve rüyasına göre iskelede devlet büyüklerinin himmeti ve âşıkların âhı misali yüksek bir minare inşa edildiğini ve teklif üzerine bu minareye çıkıp ezan okuduğunu ancak içine dehşetli bir korku düşüp canından el çektiğini söyler. Figânî’nin korkusunu yersiz bulan Kara Bâlîzâde, tebessüm eder ve geçim sıkıntısı çeken şairi bir parça teselli edebilmek için Defterdar İskender Çelebi'ye gideceğini ve ona iskelede bir görev ayarlayacağını, dolayısıyla rüyasını hayra yorması gerektiğini söyler. Figânî biraz olsun rahatlasa da üç gün sonra Tahtakale'deki evinden alınır, önce kamçılanır, sonra da eşeğe bindirilip teşhir edilir ve en sonunda iskeleye götürülüp asılır. ${ }^{24}$ Gelibolulu Mustafa Âlî de

27 Haziran 1523). Kanuni'nin kız kardeşi Hatice Sultan'la evlendi. Ahmed Paşa isyanıyla karışan Mısır'da asayişi sağlamakla görevlendirildi. Kendisine ayrıca Mısır beylerbeyi unvanı verildi. Kahire'de kaldığı müddet içinde işleri yoluna koydu (930 / 1524). İki yıl sonra yapılacak olan Macaristan seferinin serdarlığını üstlendi. Mohaç Meydan Muharebesi'nin kazanılmasında rol oynadı. Zaferden sonra padişahla birlikte girdiği Budin'deki bazı heykelleri İstanbul'a getirip sarayının bahçesine dikmesi tepkiyle karşılandı. Bunda muhaliflerin de önemli rolü olmuştu. Onun ölümünden on alt1-on yedi yıl sonra İstanbul'a gelen seyyah Hans Dernschwamm, halk arasında Arnavut asıllı olarak bilinen İbrahim Paşa'nın "gâvur" kaldığı, Hristiyanlığını gizlediği, resim ve heykellere saygı duyduğu yolundaki rivayetlerin hâlâ söylenegeldiğini ifade etmektedir. Macaristan seferinden sonra Anadolu'da tehlikeli bir şekle bürünen isyanları bastırdı. İkinci Macaristan seferinde kendisine serasker unvanı verildi. Safeviler'e karşı girişilen Irakeyn seferinde başarılı oldu. Sefer sırasında anlaşmazlığa düştüğü Defterdar İskender Çelebi'yi önce azlettirip sonra da Bağdat'ta katlettirdi. Bu hadise ve büyük yetkilerine güvenerek kendisini sultan unvanı ile anması, saray çevresinde ve padișah üzerinde olumsuz bir etkiye yol açtı. İstanbul'a dönüldükten bir müddet sonra 942 Şabanında (Şubat 1536) Fransızlara verilen ahidnamenin hazırlıkları ile uğraşan İbrahim Paşa, iftar için saraya çağrıldığı 21-22 Ramazan 942 (14-15 Mart 1536) gecesi hiçbir sebep gösterilmeden ansızın boğularak idam edildi. (Detaylı bilgi için bkz.: Feridun Emecen, "İbrahim Paşa, Makbul”, Diyanet Vakfi Íslam Ansiklopedisi, Cilt: 21, Türkiye Diyanet Vakfi Yay., İstanbul 2000, s. 333-335)

${ }^{21}$ Kınalı-zade Hasan Çelebi, age., s. 764-765. (Beytin Türkçesi şöyledir: Cihana iki İbrahim geldi. Biri put yıktı, diğeri put dikti.) Bu beyit Âşık Çelebi'de şöyledir:

Dü İbrâhîm âmed be-dâr-ı cihân

Yekî büt şiken şud yekî büt-nişân (bkz. Âş1k Çelebi, age., s. 1204.)

${ }^{22}$ Kınal1-zade Hasan Çelebi, age., s. 765.

${ }^{23}$ Detaylı bilgi için bkz.: İ. Güven Kaya, "Figânî'nin Ölümü ve Taşlıcalı Yahya Bey’in Bir Şiiri”, Atatürk Üniversitesi Türkiyat Araştırmaları Enstitüsü Dergisi, Sayı: 34, 2007, s. 57-59.

${ }^{24}$ Âş1k Çelebi, age., s. 1207-1209. 
şairin bir seher vakti Tahtakale'deki evinden alınıp teşhir edildiğini, ardından Balıkpazarı'ndaki darağacına götürülüp asıldığını büyük bir esefle dile getirir. Şair öyle alelacele katledilmiştir ki Defterdar İskender Çelebi'nin duyup şairi kurtarmak için firsatı bile olmamıştır. ${ }^{25}$

Sehî Bey, "Nazik kişilerden birisi bu durumu hicveden bir beyit söylemiş. Bazı muarızları da bu beyti Figânî dedi diye gammazlamışlar. Hiçbir şeyden haberi olmayan Figânî, bunun üzerine yakalanıp idam ettirilmiş." diyerek söz konusu beytin Figânî’ye ait olmadığını belirtir. ${ }^{26}$ Ahdî’nin "Nâgâh kazâ-yı âsmânî ve belâ-yı nâgehânîye râst gelüp ol ser-efrâze töhmet-i gammâz ugrayup bir matla-ı hicv-âmîz vezîr olan İbrâhîm Paşa hakkında dimişler diyü salbine emr olunmış. Dâr-ı İstanbul'da ber-dâr olup ser-efrâz-ı dünyâ ve mümtâz-ı ukbâ olmış." şeklindeki ifadelerinden Sehî Bey'le aynı görüşte olduğu anlaşılmaktadır. ${ }^{27}$ Âşık Çelebi ise "İbrâhîm Paşa-yı merhûm hakkında ırz-l vezâreti tahkîr itdi diyü salb itdiler, anda aslâ harf-i illet yogiken yok yirlere elif-i dâra kalb itdiler. Dâr-ı dünyâda anun sebeb-i şehâdetine ve kat'-l rişte-i ta'allukına nümûdâr oldı ve şu'arâ içinde ulüvv-i kadr ve rif'at-i pâyesine medâr oldı." diyerek Figânî'nin haksız yere katledildiğini ayrıca "Bu beyt Selâtîn-i Acem'den Sultân İbrâhîm nâmına dinmiş eski beyt imiş, bir meclisde münâsebetle okındukda Figânî be-dâr-l cihân yirine be-deyr-i cihân büt lafzına çesbândur dimişdür, yogsa beyt anun degüldür." cümlesiyle de beytin Acem hükümdarlarından Sultan İbrahim'i hicvetmek için başkası tarafindan nazmedildiğini ve bir mecliste konusu geçip okunduğunda Figânî'nin beyitteki "büt" kelimesinden hareketle "be-dâr-ı cihân" yerine "be-deyr-i cihân" terkibinin daha uygun düşeceğini söylediğini ifade eder. ${ }^{28}$ Çünkü beytin çok daha eski zamanlarda, Gazneli Mahmud devrinde söylenmiş olduğuna dair kayıtlar vardır. ${ }^{29}$ Riyâzî, "Ba'zı a 'dâsı vezîr-i a'zam İbrâhîm Paşa'yı hicv itdi diyü miyân-ı âlemiyânda bu beyti ifşâ itmişler idi.” sözleriyle Figânî’nin düşmanlarının iftirasına kurban gittiğine dikkat çeker. ${ }^{30}$ Gelibolulu Mustafa Âlî de diğer tezkireciler gibi Figânî'nin, kendisine ait olmayan bir beyitle itham edilerek hayatının karartıldığı görüşündedir. ${ }^{31}$ Beyânî, bu konuyla ilgili herhangi bir bilgi vermezken dönemin bir diğer tezkirecisi Latîfî ise "dili ucından cihân-ı vasî'de yerini dâr ve sırr-ı ene'l-hakdan râz açmadın iledüp Mansûr-vâr berdâr itdiler" ifadeleriyle şairin dili yüzünden idam edildiğini söyleyerek beytin Figânî’ye ait olduğu kanısında görünür. ${ }^{32}$ Latîfî ${ }^{33}$ ve Gelibolulu Mustafa Âlî; ${ }^{34}$ Figânî'nin, katledilmeden birkaç gün önce aşağıdaki beyti söylediğini hayretle kaydederler:

Zülfi kemendin ald'ele cellâd gamzesi

Benzer Figânî zulm ile ber-dâr ider seni

Kesin olarak konuşmak güç olmakla birlikte çoğunluğun görüşünden ve açık anlatmalardan hareketle, beytin Figânî’ye ait olmadığı ve şairin kendisine çalınan bir karaya kurban gittiği anlaşılmaktadır. Figânî'nin ölüm yılı Âşık Çelebi, ${ }^{35}$ Gelibolulu Mustafa Âlî, ${ }^{36}$ Riyâzîi ${ }^{37}$ ve Kâf-zâde Fâ'izî’de ${ }^{38} 938$ / 1531-32 olarak kayıtlıdır. Katledilişinden birkaç gün önce gördüğü rüyayı anlattığı eğlencenin bahar mevsiminde düzenlendiği Âşık Çelebi

\footnotetext{
${ }^{25}$ Künhü'l-Ahbâr'in Tezkire Kısmi, s. 256-257.

${ }^{26}$ Sehî Bey Tezkiresi Heşt Behişt, s. 225.

${ }^{27}$ Ahdî ve Gülşen-i Şu'arâsı (İnceleme-Metin), s. 466.

${ }^{28}$ Âş1k Çelebi, age., s. 1204.

${ }^{29}$ A. Karahan, agmd., s. 58.

${ }^{30}$ Riyâzî Muhammed Efendi, age., s. 260.

${ }^{31}$ Künhü'l-Ahbâr'ın Tezkire Klsmi, s. 256.

${ }^{32}$ Latîfî, age., s. 439.

${ }^{33}$ Latîfî, age., s. 440.

${ }^{34}$ Künhü'l-Ahbâr'ın Tezkire Klsmi, s. 257.

${ }^{35}$ Âş1k Çelebi, age., s. 1209.

${ }^{36}$ Künhü'l-Ahbâr'ın Tezkire Kısmı, s. 257.

${ }^{37}$ Riyâzî Muhammed Efendi, age., s. 262.

38 Bekir Kayabaşı, Kâf-zâde Fâ'izî'nin Zübdetü'l-Eş'âr' l, Yayımlanmamış DT, İnönü Üniversitesi, SBE, Malatya 1997, s. 448.
} 
tarafından ima edildiğine göre şairin ölümünün 1532 yılı ilkbaharına denk geldiğini söylemek yanlış olmaz. ${ }^{39}$

Delikanlılı̆̆ına bile doyamayan ve henüz otuz yaşına basmadan öldürülen Figânî'den kusursuz şiirler beklemek haksızlık olur. Çıraklık dönemini tamamlayamadan ömrünün böyle acı bir sonla bitmesi, şiirlerinde belirli bir mükemmelliği yakalayamamasına sebep olmuştur. Mevcut şiirleri ortadadır. Yapılacak değerlendirmeler, mevcut şiirleri üzerinden yapılmalıdır. Döneminin eleştirmenleri sayılan tezkire yazarları, bu durumu da hesaba katarak Figânî'nin güzel şiirler yazdığını, ecelden aman bulsaydı daha da güzellerini yazabileceğini dile getirirler. Bu konuda âdeta ittifak ederler. ${ }^{40}$

Sehî Bey, Figânî’nin kabiliyetli bir şair olduğunu söyler. ${ }^{41}$ Âşık Çelebi; şiirlerinin âş̧kane ve ahenkli, karakterinin düzgün, gazel ve kasidelerinin mana ve sanat açısından zengin olduğunu ifade eder. ${ }^{42}$ Latîfî; şiir yazmaya daha yeni başladığı çağlarda bile orijinal ifadeler ve ince hayaller kullandığına, eğer ecel müsaade etseydi Nizâmî gibi şöhret yakalayıp çağdaşı diğer şairlerden daha gösterişli bir divan ortaya koyabileceğine ve kısa ömrüne rağmen zekâsıyla döneminin büyük şairleri arasına girebilmeyi başardığına değinir. ${ }^{43}$ Ahdî; Figânî’nin kuvvetli bir şair olup akıcı ve büyüleyici bir söyleyiş tarzına sahip olduğuna ve bu sayede şiirlerinin rağbet gördüğüne, ayrıca kaside ve gazel yazmakta emsalinin bulunmadığına dikkat çeker. ${ }^{44}$ Beyânî; şiirlerinin dertli âşıkların âhı misali gönülleri yaktığına, belagatle yoğrulan kelimelerinin saflıkta temiz bir suyu andırdığına, gazellerini vasfetmekte kalemin âciz kalacağına, kasidelerinin ise sanatlı ve nazire yazılamayacak kadar etkileyici olduğuna vurgu yapar. ${ }^{45}$ Kınalızade Hasan Çelebi; şiirlerinin fasih ve beliğ, lafzının düzgün ve akıcı, kasidelerinin ise sanatkârâne olduğunu belirtir. ${ }^{46}$ Riyâzî, tumturaklı lafizlarla kasideler söylediği ve kendisinden sonra yetişen birçok şairi etkilediği görüşündedir. ${ }^{47}$ Gelibolulu Mustafa Âlî ise Âşık Çelebi'nin Figânî'yi övme noktasında ileri gittiğini söyler ve kasideleri üzerinden şairi eleştirir. Ancak ömrü vefa etseydi meşhur şairler arasına dâhil olabileceğini ve akıcı üsluba malik olup bazı anlamsız ifadeleri kullanmaktan kurtulabileceğini ifade eder. ${ }^{48}$ Âlî’nin böyle bir eleştirme yapması, daha çok tarihçi olmasındandır. Tezkirecilerde genel olarak bu türden eleştirmelere pek rastlanmaz. Âlî’nin görüşünde doğrunun da yanılmanın da payı vardır. $\mathrm{Ne}$ olursa olsun Sehî'den Âlî’ye kadar XVI. yüzyıl tezkireci ve şairlerinden Figânî konusunda söz söyleyenler onun sanat gücünü belirtmişler, orijinal buluşlarına parmak basmışlar ve yeteri kadar yaşamış olsaydı büyük üstatlar arasında yer alabileceğini kabul etmişlerdir. ${ }^{49^{3}}$

Büyük Acem üstatlarının eserlerini çok iyi tetebbu ettiği muhakkak olan Figânî; Ahmed Paşa ve Necâtî'nin tesirinden kurtulamamakla beraber, bilhassa İran kasidecilerinden sık sık istifade etmiştir. ${ }^{50}$ Aşınmamış, az kullanılmış hatta bazen kullanılmamış, garip gözükebilecek hayallere düşkünlüğü yanında, nükteleri, buluşları ve özellikle mısralara becerikli biçimde sıkıştırmaya güç yetirdiği atasözleri ve deyimlerle Figânî; daha yaşadığı günlerde bile dikkatleri üzerine çekmesini bilmiş, beğenilmiştir. Çağına göre şiir dilinin sadeliği, duygularının inceliği ve sürekli coşkunluğu yanında atasözü ve deyim haznelerinde bulduğu incileri de nazım ipliğine

\footnotetext{
${ }^{39}$ A. Karahan, age., s. XXII, XXIII.

${ }^{40}$ C. Çiftçi, age., s. 186.

${ }^{41}$ Sehî Bey Tezkiresi Heşt Behişt, s. 225.

42 Âş1k Çelebi, age., s. 1203.

${ }^{43}$ Latîfî, age., s. 438-439.

${ }^{44}$ Ahdî̀ ve Gülşen-i Şu'arâsı (Inceleme-Metin), s. 466.

${ }^{45}$ Beyâni Mustafa Bin Carullah, age., s. 211-212.

${ }^{46}$ Kinali-zade Hasan Çelebi, age., s. 763-764.

${ }^{47}$ Riyâzî Muhammed Efendi, age., s. 260.

${ }^{48}$ Künhü'l-Ahbâr'ın Tezkire Klsmi, s. 257.

${ }^{49}$ A. Karahan, age., s. XXVII.

${ }^{50}$ M. Fuad Köprülü, “Figânî”, İslâm Ansiklopedisi, Cilt: 4, Millî Eğitim Bakanlığı Yay., İstanbul 1964, s. 631.
} 
dizmesini iyice bilmiş olması, onun ün kazanmasına, maceralarla geçen hayatı gibi şiirlerinin de dilden dile dolaşmasına yol açmıştır. ${ }^{51}$

Figânî’nin genç yaşta katledilmesi, ne yazık ki şiirlerini bir araya getirip bir divan tertip etmesine imkân vermemiştir. Ölümünün ardından şiirleri de müstakil bir divanda toplanmamıştır. Ancak Abdülkadir Karahan, yurt içi ve yurt dışı kütüphanelerde bulunan şiir mecmualarından şaire ait manzumeleri toplamış ve 8 kaside, 107 gazel ve 2 tahmisten oluşan bir Divançe $^{52}$ yayımlamıştır. Saf bir üsluba ve güçlü bir nazım tekniğine sahip olan Figânî’nin bilhassa XVI. yüzyıl mecmuaları başta olmak üzere farklı birçok şiir mecmuasında kaside ve gazellerine tesadüf etmek genellikle mümkündür.

Şiir mecmuaları, şiirden anlayan ve belli bir şiir zevkine sahip olan kişiler tarafından tertip edilmesinin yanında toplumun beğenisinin de hesaba katılarak oluşturulduğu mühim eserlerdir. Edebiyat tarihimiz açısından büyük önem arz eden şiir mecmuaları, divan sahibi birçok şairin divanında yer almayan şiirleri ihtiva etmeleri ve döneminin şiir zevkini yansıtmaları açısından eşsiz birer hazine niteliği taşırlar. Bunun yanında literatürde kendisine dair bilgi bulunmayan şairlerin ve şiirlerinin tespitinde, ayrıca basılı divanlardaki şiirlerin eksikliklerinin giderilmesinde ve çeşitli nedenlerden hâsıl olan yanlış okumaların düzeltilmesinde mecmualar, önemli başvuru kaynakları konumundadır.

Divanlarda ve(ya) divan neşirlerinde yer almayan şiirlerin sadece mecmualarda bulunmasının birçok nedeni olabilir. Şair, divanını tertip ederken sadece beğendiği şiirlerin divanında yer almasını istemiş olabilir veya bazı şiirleri karalama hâlinde kalmış ve mecmua derleyicisi bunları görüp eserine almıştır. Aynı şekilde şairin, divanını tertip ettikten sonra kaleme aldığı şiirlerini divanına almasına ömrü vefa etmemiştir. Belki mecmuayı teşkil eden müstensihin gördüğü nüsha kaybolmuştur ya da divanları neşreden araştırmacılar bütün nüshaları görmemiştir. Belki de bu şiirleri mecmuaya müstensihin kendisi ilave etmiştir veya aynı mahlaslı şairleri karıştırmıştır. Bu nedenleri çoğaltmak gayet mümkün olmakla beraber şiir mecmualarının klasik Türk edebiyatı araştırmacıları açısından önemi yadsınamaz bir gerçektir. ${ }^{53}$

Bazı şiirlerine sadece şiir mecmualarında rastladığımız şairlerden biri de Figânî'dir. Bu çalışmada Figânî'nin yayımlanmayan bir gazeli neşredilecektir. Bu anlamda Abdülkadir Karahan'ın mezkûr çalışması ${ }^{54}$ esas alınmış ve bir şiir mecmuasından hareketle bu çalışmada yer almayan 2 gazel tespit edilmiştir. Söz konusu gazeller, Topkapı Sarayı Müzesi Kütüphanesi Revan $1985^{55}$ (TSMK) numarada kayıtlı olan şiir mecmuasının içerisindedir. Zâtî, Bâkî, Behiştî, Cinânî, Hamdî, Emrî, Figânî, Fuzûlî, Hayâlî, Hayretî, Usûlî, Ulvî, Rahmî, Meylî, Muhibbî, Rûhî, Hâletî, Riyâzî, Yahyâ, Cevrî, Veysî ve Nef'î... gibi daha çok XVI ve XVII. yüzyı1 şairlerinin şiirlerini ihtiva eden 173 varaklık bu mecmuada Figânî'nin -Divançesinde bulunmayan 2 gazeliyle birlikte- toplam 11 şiiri yer almaktadır. Şairin Divançesinde tespit edilemeyen bu 2 gazelden biri aynı zamanda Millî Kütüphane Yazmalar Koleksiyonu 06 Mil Yz A 1998 (MK) numarada kayıtlı olan şiir mecmuasının 62a varakında da mevcuttur. Söz konusu bu gazel yayımlanmıştır. ${ }^{56}$

\footnotetext{
${ }^{51}$ Abdülkadir Karahan, “Trabzonlu Figânî’de Atasözleri ve Deyimler”, TDED, Sayı: 23, 1981, s. 174.

${ }^{52}$ A. Karahan, age.

${ }^{53}$ Beyhan Kesik vd., "Bir Şiir Mecmuasından Hareketle Muhibbî’nin Yayımlanmamış Şiirleri”, International Journal of Language Academy, Cilt: 3, Say1: 1, 2015, s. 362.

${ }^{54}$ A. Karahan, age.

${ }^{55}$ Mecmua hakkında detaylı bilgi için bkz.: Semra Tunç, "Topkapı Sarayı Müzesi Kütüphanesi Revan 1985 Numaralı Şiir Mecmûası”, Selçuk Üniversitesi Türkiyat Araştırmaları Dergisi, Sayı: 18, 2005, s. 11-87.

${ }^{56}$ Detaylı bilgi için bkz.: Ferdi Yorgun, “Figânî’nin Yayımlanmamış Bir Gazeli”, Littera Turca Journal of Turkish Language and Literature, Cilt: 2, Say1: 2, 2016, s. 147-154. Zikri geçen her iki mecmuada da herhangi bir nüsha farkına rastlanmayan bu gazel 5 beyitten müteşekkildir:

Mef’ūlü fã‘ilātü mefā‘īilü fā‘ilün

Gördi nihāl-i kāmetini sen semen-berüñ

Biñ pāre oldı kalbi hasedden șanavberüñ
} 
Așağıda transkribe edilmiş metni verilen gazelle Figânî'nin Divançesinde yer alan gazeller arasında üslup, içerik, anlam, kullanılan kelimeler, hayal dünyası ve edebî sanatlar açısından büyük benzerlikler görülmektedir. Şairin Divançesindeki gazellerde teneffüs edilen lirik havayı aşağıdaki gazelde de solumak gayet mümkündür. Her şeyden önce bu gazel, Figânî'nin şairlik fitratına, söyleyiş tarzına ve şiir tekniğine uygundur. Zira çalışmamıza konu olan gazel ile şairin mevcut şiirleri mukayese edildiğinde; kullanılan dilin sadeliği, tercih edilen kelimelerin ortaklığı ya da benzerliği, âş̧k ve sevgili için yararlanılan benzetme ögeleri vb. açılardan önemli müşterek hususiyetler göze çarpmaktadır.

Figânî, ilgi çekici bir cinasla başladığı gazelinin matla beytinde sevgilinin dudağının can ve gönül derdine ilaç olduğunu söylemekte, dolayısıyla hastalığını iyileştirmesi için sevgiliden dudağını lütfetmesini talep etmektedir. "Dudak, divan şairlerinin en çok üzerinde durduğu güzellik unsurlarından biridir. Cinsî açıdan öpmek, emmek, sormak, ağza almak, buse almak vs. fiillerle birlikte kullanılır. Canın son çıkış noktası dudak olduğu için can ile yakından ilgilidir. $\mathrm{Bu}$ noktada dudaktan dökülen can bağışlayıcı kelimeler de önem kazanır. Dudak; nitelik bakımından bir tabip, darüşşifa, ilaç, deva, em, gülşeker ve tiryaktır. Dolayısıyla âşı̆̆a can bağışlayan her türlü meziyet ve ilaç dudakta mevcuttur." ${ }^{57}$ Şair, "emdür" sözcügüyle yaptığ 1 oyuna ikinci beyitte de devam etmekte ve "nemdür" (nemlidir/neyimdir) kelimesindeki iham yoluyla okuyucuyu vehme düşürmektedir. Uzun boyuyla servi ağacını andıran sevgiliye seslenen âşı; ondan, uğruna döktüğü gözyaşlarının, ayağına akmasına müsaade etmesini istemektedir. Âşığın, sevgiliye sahip olmak adına elinde bulundurduğu en büyük sermayesi gözyaşıdır. Zira âşık, sevgili için döktüğü gözyaşlarının çokluğuyla övünür. Dolayısıyla âşığın değer kazanması için çok ağlaması gerekir. Zaten sevgilinin istediği de budur. Servi ağaçları genellikle su kenarlarında bulunur. Bu düşünceden hareketle şair, âşığın gözyaşlarıyla nehir / ırmak arasında bir benzerlik ilgisi kurmaktadır. Üçüncü beyte göre bela ülkesinin sultanı olan gönlün yardımcıları / orduları gam ve kederdir. Divan şiirinde âşık, sevgiliye kavuşamamanın verdiği 1stırapla sürekli gamlıdır. Gönlün bela ülkesinin sultanı olması, âşığın daima gamlı oluşu, daha doğrusu gamlı olmak istemesiyle alakalıdır. Çünkü gam, sevgiliden gelir ve âşığı olgunlaştırır. Ayrıca âşı̆̆ın, sevgilinin gözündeki değeri, çektiği acının derecesi ve bu acıya rağmen hâlâ aşk yolunda istekli kalabilmesiyle ölçülür. İşte bu yolda gönlün en vefalı dostları gam ve kederdir. Zira gam ve keder, ömür boyu âşıktan hiç ayrılmaz. Dördüncü beyitte sevgilinin göz alıcı güzellik unsurlarından olan ağzı, boyu ve saçından ayrı kalan âşığın tek dert ortağının elem olduğu belirtilmektedir. Sevgilinin ağzı, boyu ve saçı divan şairlerinin şiirlerine en çok konu ettikleri güzellik kavramlarındandır. Ağız; küçüklügü hatta bazen hiç olmayışıyla dikkat çeker. $\mathrm{O}$, bu özellikleriyle bazen goncayı, bazen mim harfini bazen de noktayı çağrıştırır. Sevgilinin boyu düzgün ve uzundur. Bu niteliğinden dolayı boy, daha önce de değinildiği üzere serviye benzetilir. Hafif hafif esen rüzgârda salınan servi ağacı, sevgilinin işveli yürüyüşünü andırır. Bu nazlı yürüyüş ise âşıklar arasında kıyametin kopmasına sebep olur. Şairin beytine güzellik katan bir diğer unsur ise saçtır. Birçok edebî sanata konu olan saç; kokusu, rengi ve şekli itibariyle âşıkların derdine dert katar. Sevgilinin ağzı, boyu ve saçı âşıkların en çok arzu ettikleri şeylerdir. İşte bunlardan ayrı kalan âşığın tek arkadaşı ve onu teselli edecek olan tek dostu elemdir. Şair, makta beytinde kendisini soyutlamakta ve bülbül gibi ağlayıp feryat etmesine gül yüzlü, gonca ağızlı sevgilinin sebep olduğunu ifade etmektedir. Divan şiirinde gül sevgiliyi, bülbül ise âşı̆̆ı temsil eder. Âşı̆̆ın sevgiliye olan aşkını ifade etmeye çalışması ile

Tagit efendi gül yüzüñ üstine sünbülün Yüzi karası yanına kalsun ko 'anberün Zāhid şarāb-ı la 'lüñi nūş eyleyeydi ger Hergiz cihānda adını añmazdı kevserüñ La 'lüñ nebātı virdi kesāda benüm begüm İsin bitürdi kāmet-i mevzūnuñ 'ar'aruñ Kimdür dir iseñ ey şeh-i hüūān Fì̈āniyi

Bir derd esīri 'āşılk-ı şūrīde kemterüñ (TSMK 95a/MK 62a)

${ }^{57}$ İskender Pala, Ansiklopedik Divân Şiiri Sözlüğ̈̈, Kap1 Yay., İstanbul 2009, s. 285. 
bülbülün gülün dalına konarak ötmesi arasında bir bağ kurulur. Beyitlerde çok sık karşılaşılan bir çiçek türü olan gül, rengi ve şekli bakımından sevgilinin yüzü ve yanağı için benzetilen olur. Sevgilinin ağzı ise şekil itibariyle goncaya teşbih edilir. Goncanın handan olması, açılması anlamına gelir. İşte âşığın bülbül misali ağlayıp inlemesine neden olan şey, gül yüzlü ve gonca ağızlı sevgilidir.

Figânî’nin Yayımlanmamış Gazeli ${ }^{58}$

(Mefā‘îlün Mefā‘īlün Fe‘ūlün)

1. Lebüñ kim cān u dil derdine emdür Anı ben hasteye lutf eyle emdür

2. Ko aksun pāyüñe eşk-i revānum Gözüm yaşı benüm ey serv nemdür

3. Belā iḳīminüñ sulțānıdur dil Gam u gușṣa aña hayl ü haşemdür

4. Dehān u kāmet ü zülfüñon ayru Nigārā hem-demüm ancak elemdür

5. Seni bülbül gibi zār eyleyen hep Fì̈ānī ol yüzi gül gonca-femdür

\section{Sonuç}

Kendisine isnat edilen Farsça bir beyit yüzünden katledilen Figânî, -dönemin bütün tezkirecilerinin ittifakla belirttiği üzere- şayet ömrü vefa etseydi XVI. yüzyılın en büyük şairleri arasındaki yerini alacaktı. Âşıkane gazelleri, akıcı üslubu, orijinal hayalleri ve mazmunlarıyla daha çok genç yaşta iken şöhretin kapılarını aralayan şair, elinden tutacak bir hamisinin olmayışı ve hazin ölümü sebebiyle sanatını hakkıyla icra edememiş, dolayısıyla okuyucuları gönül yakan üslubuyla buluşturabilecek bir divan ortaya koyamamıştır. Ancak mevcut şiirleri, Figânî’nin ne kadar büyük bir şair olduğunu gözler önüne sermek için yeterli etkileyiciliğe sahiptir. Bugüne kadar şair hakkında yapılan en ciddi çalışma ile 8 kaside, 107 gazel ve 2 tahmisten oluşan Divançesi ilim âlemine kazandırılmıştır. Bilindiği üzere edebiyatımızın karanlık dünyasına 1şık tutan en önemli kaynaklarımızdan olan mecmualar, şairlerin çeşitli sebeplerle divanlarına dâhil etmedikleri şiirlerini gün yüzüne çıkarma hususunda büyük bir boşluğu doldurmaktadır. Bu çalışma ile de Figânî'nin Divançesinde yer almayan gazeller zincirinin bir halkası daha tamamlanmış ve şairin yayımlanmayan 5 beyitlik gazelinin metni sunulmuştur.

\section{Kaynakça}

Ahdî ve Gülşen-i Şu'arâsı (İnceleme-Metin), Haz. Süleyman Solmaz, Atatürk Kültür Merkezi Başkanlığ Yay., Ankara 2005.

Âşık Çelebi, Meşâ 'irü'ş-Şu'arâ İnceleme-Metin, C. III, Haz. Filiz Kılıç, İstanbul Araştırmaları Enstitüsü Yay., İstanbul 2010.

Beyâni Mustafa Bin Carullah, Tezkiretü'ş-Şuarâ, Haz. İbrahim Kutluk, Türk Tarih Kurumu Yay., Ankara 1997.

Çiftçi, Cemil, Maktul Şairler, Kitabevi Yay., İstanbul 1997.

\footnotetext{
${ }^{58}$ TSMK 110b.
} 
Emecen, Feridun, “İbrahim Paşa, Makbul”, Diyanet Vakfi İslam Ansiklopedisi, Cilt: 21, Türkiye Diyanet Vakfi Yay., İstanbul 2000.

Karahan, Abdülkadir, "XVI. Asır Divan Şairlerinden Figânî ve Şiirleri”, İstanbul Üniversitesi Edebiyat Fakültesi Türk Dili ve Edebiyatı Dergisi, Sayı: 3 (3-4), 1949, s. 389-410.

Karahan, Abdülkadir, Kanunî Sultan Süleyman Çağı Şairlerinden Figan̂̂ ve Divançesi, İstanbul Üniversitesi Edebiyat Fakültesi Yay., İstanbul 1966.

Karahan, Abdülkadir, “Trabzonlu Figânî’de Atasözleri ve Deyimler”, TDED, Sayı: 23, 1981, s. 165-174.

Karahan, Abdülkadir, "Figânî", Diyanet Vakfi İslam Ansiklopedisi, Cilt: 13, Türkiye Diyanet Vakfi Yay., Ankara 2018.

Kaya, İ. Güven, “Figânî’nin Ölümü ve Taşlıcalı Yahya Bey’in Bir Şiiri”, Atatürk Üniversitesi Türkiyat Araştırmaları Enstitüsü Dergisi, Sayı: 34, 2007, s. 47-61.

Kayabaşı, Bekir, Kâf-zâde Fâ'izî'nin Zübdetü'l-Eş'âr'l, Yayımlanmamış DT, İnönü Üniversitesi, SBE, Malatya 1997.

Kesik, Beyhan, Zehra Pehlivan, Emre Şengül, "Bir Şiir Mecmuasından Hareketle Muhibbî’nin Yayımlanmamış Şiirleri”, International Journal of Language Academy, Cilt: 3, Sayı: 1, 2015, s. 361-373.

Kınalı-zade Hasan Çelebi, Tezkiretü'ş-şuarâ, C. II, Haz. İbrahim Kutluk, Türk Tarih Kurumu Yay., Ankara 1989.

Köprülü, M. Fuad, “Figân̂̂”, İslâm Ansiklopedisi, Cilt: 4, Millî Eğitim Bakanlığı Yay., İstanbul 1964, s. 630-631.

Künhü'l-Ahbâr'ın Tezkire Kısmı, Haz. Mustafa İsen, Atatürk Kültür Merkezi Yay., Ankara 1994.

Latîfî, Tezkiretü'ş-Şu'arâ ve Tabsıratü'n-Nuzamâ (İnceleme-Metin), Haz. Rıdvan Canım, Atatürk Kültür Merkezi Başkanlığı Yay., Ankara 2000.

Mehmed Süreyyâ, Sicill-i Osmanî Yahud Tezkire-i Meşâhir-i Osmâniyye, C. IV/I, Hazırlayanlar: Mustafa Keskin-Ayhan Öztürk-Hamdi Savaş-Havva Kurt, Sebil Yay., İstanbul 1997.

Mehmet Nâil Tuman, Tuhfe-i Nâilî Divân Şâirlerinin Muhtasar Biyografileri, C. II, Hazırlayanlar: Cemâl Kurnaz-Mustafa Tatcı, Bizim Büro Yay., Ankara 2001.

Pala, İskender, Ansiklopedik Divân Şiiri Sözlüğü, Kapı Yay., İstanbul 2009.

Riyâzî Muhammed Efendi, "Riyâzü’ş-Şuara", Haz. Namık Açıkgöz, http://ekitap.kulturturizm.gov.tr/Eklenti/54137,540229-riyazu39s-suarapdfpdf.pdf?0, erişim tarihi: 19.12.2018.

Sehî Bey Tezkiresi Heşt Behişt, Haz. Mustafa İsen, Akçağ Yay., Ankara 1998.

Şemsettin Sâmi, Kâmûsu'l-A’lâm, C. V, Kaşgar Neşriyat, Ankara 1996.

Tunç, Semra, "Topkapı Sarayı Müzesi Kütüphanesi Revan 1985 Numaralı Şiir Mecmûası", Selçuk Üniversitesi Türkiyat Araştırmaları Dergisi, Sayı: 18, 2005, s. 11-87.

Yorgun, Ferdi, "Figânî'nin Yayımlanmamış Bir Gazeli”, Littera Turca Journal of Turkish Language and Literature, Cilt: 2, Say1: 2, 2016, s. 147-154. 
Ek:



Topkapı Sarayı Müzesi Kütüphanesi, Revan 1985, vr. 110b. 